\title{
Comparative analysis of prostatic acid phosphatase and prostate-specific antigen mRNA levels in hyperplastic prostate stimulated with steroid hormones and growth factors ${ }^{\star \star}$
}

\author{
Joanna Dulińska ${ }^{\bowtie}$, Piotr Laidler and Maria Łabędź \\ Institute of Medical Biochemistry, Medical College, Jagiellonian University, Kraków, Poland
}

Received: 16 November, 2001; revised: 22 April, 2002; accepted: 10 June, 2002

Key words: hyperplastic prostate, prostatic acid phosphatase, prostate-specific antigen, androgens, growth factors

\begin{abstract}
Prostatic acid phosphatase (PAP) and prostate-specific antigen (PSA) are the markers of human prostatic gland. However, it is still not completely understood if and how, steroid hormones and growth factors affect their expression and metabolism in the respect to the major pathologies of the gland. Appropriate studies were carried out on histopathologically diagnosed benign prostatic hyperplasia - BPH $(n=42)$ using tissue slices and cells derived from them. They were incubated with steroid hormones: 5- $\alpha$-dihydrotestosterone (DHT), estradiol (E) and growth factors: epidermal growth factor (EGF), basic fibroblastic growth factor (bFGF) under culture conditions for up to 24 hours. ${ }^{32}$ P-labelled specific oligonucleotide probes were used to analyze total RNA isolated from each sample for the presence of PAP and PSA mRNAs.

DHT, E, bFGF, EGF or both DHT + bFGF and DHT + EGF increased PAP and PSA mRNA levels in a time- and dose-dependent manner. The highest and statistically significant increase $(P<\mathbf{0 . 0 0 1})$ for PAP mRNA was observed when DHT + bFGF were present in the medium while for PSA mRNA if DHT + EGF were added to the medium.
\end{abstract}

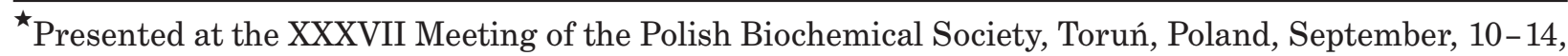
2001.

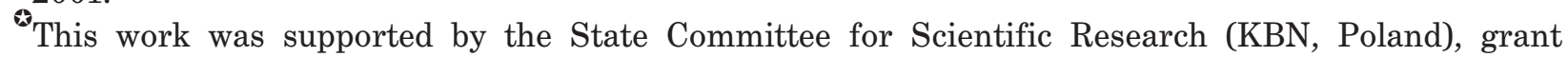
Wł/18/P, Medical College, Jagiellonian University, Kraków.

${ }^{\otimes}$ Correspondence to: Joanna Dulińska, Institute of Medical Biochemistry, Medical College, Jagiellonian University, 31-034 Kraków, M. Kopernika 7, Poland; tel./ fax. (48 12) 4223272 , e-mail: mblitewk@kinga.cyf-kr.edu.pl
}

Abbreviations: AR, androgen receptor; $\mathrm{BPH}$, benign prostatic hyperplasia; DHT, 5- $\alpha$-dihydrotestosterone; E, estradiol; EGF, epidermal growth factor; EGFR, epidermal growth factor receptor; bFGF, basic fibroblastic growth factor; FCS, fetal calf serum; K2, human prostate-specific glandular kallikrein; $\mathrm{NaCl} / \mathrm{P}_{\mathrm{i}}$, phosphate-buffered saline; PAP, prostatic acid phosphatase; PC, prostatic carcinoma; PMSA, prostate-specific membrane antigen; PSA, prostate-specific antigen; SF, steroid free fetal calf serum; TGF- $\alpha$ and TGF- $\beta$, transforming growth factors alpha and beta. 
Slow but constant decrease of PAP and PSA mRNA levels was observed in the absence of each of these factors in the incubation medium. The results suggest that early expression of PSA and PAP genes and/or their mRNA stability strongly depend on DHT while differ in their response to EGF and bFGF.

Benign prostatic hyperplasia $(\mathrm{BPH})$ is very common in men. Steroid hormones - testosterone, its derivative 5- $\alpha$-dihydrotestosterone (DHT) and estradiol (E) as well as growth factors like epidermal growth factor (EGF), transforming growth factors alpha and beta (TGF- $\alpha$ and TGF- $\beta$ ) and basic fibroblastic growth factor (bFGF) are among the most important factors that influence the development and function of the prostate gland. They are also involved in progression of prostatic pathology - BPH and prostate carcinoma (PC) (Mydlo et al., 1988; Geller, 1990; Pilarsky et al., 1998). Clinical trials are currently underway to lower the intracellular level of DHT and/or estrogens in benign prostatic hyperplasia (Farnsworth, 1996). The rational background for such an approach is the assumption that androgens (testosterone, DHT) are somehow involved in the development of $\mathrm{BPH}$, while estradiol and estrone were found in hyperplastic tissue in a manifold higher content than in the concentration plasma and skeletal muscle (Krieg et al., 1997).

The accumulation of bFGF in BPH is due to the increased synthesis of the factor in the adenomatous tissue itself and to increased synthesis by prostate fibroblasts of the stroma within the prostate. It is stored in the extracellular matrix and acts as a mitogen on the stroma (Guenette \& Tenniswood, 1994; Saez et al., 1999). EGF directly stimulates the proliferation of both epithelial cells and prostate fibroblast in vitro (Guenette \& Tenniswood, 1994) and there seems to be a direct relationship between the amount of EGF and androgen in $\mathrm{BPH}$, and the production of EGF receptor (EGFR) and androgen receptors (AR), respectively. The close relations between androgens and EGF form a bridge between the paracrine and endocrine regulation of the prostate metabolism.
Prostatic acid phosphatase (PAP) is still used together with prostate-specific antigen (PSA) - the major marker of the prostate carcinoma - and prostate-specific membrane antigen (PMSA) in diagnosis of pathological changes of prostate tissue (Cooper \& Foti, 1974; Robert et al., 1995; Heston, 1996). Clinical studies have shown that the serum level of PAP and PSA in patients with prostatic carcinoma decrease in response to endocrine manipulations by estradiol treatment or orchitectomy. The results obtained from measurements of PAP and PSA serum levels in cancer patients after endocrine therapy suggest a similar androgen dependency for the regulation of expression of both these genes (Pamies \& Crawford, 1996). However, it appears that, in e.g. the LNCaP cell line, the genes of these two prostate-specific proteins, PAP and PSA are inversely regulated. The majority of studies performed to determine the hormonal regulation of the expression and metabolism of both these proteins and carried out on established prostate cancer cell lines - LNCaP, DU-145 and PC-3 - brought controversial results (Janssen et al., 1995). Down-regulation of PAP by androgens has been reported in the prostatic carcinoma cell line LNCaP (Henttu \& Vihko, 1992), whereas several studies support the opposite effect of the hormone (Lin et $a l$. , 1993). Furthermore, the androgen dependency of PSA and human prostate-specific glandular kallikrein (K2) has been clearly demonstrated (Murtha et al., 1993). Several investigations have shown that PSA and K2 gene expression is not strictly restricted to the prostate. Low levels of PSA have also been detected in the milk of lactating women and in normal breast cells or breast tumour (Diamandis \& Yu, 1995). On the contrary, studies using monoclonal antibodies against PAP have indicated prostate specificity of this protein, and PAP mRNA expression has never 
been reported outside the prostate (Solin et al., 1990).

Based both on studies of BPH tissue and on two androgen-dependent cancer cell lines, LNCaP and ALVA101, it seems that there is a complex interaction between EGF and androgen: LNCaP cells possess EGF receptors that are up-regulated by androgens. The cells secrete EGF and a closely related peptide, TGF- $\alpha$. Their growth is increased by EGF and, separately, by androgens. In contrast, both EGF and androgens additively downregulate secretion of PAP, and the mRNA level of both PAP and the nuclear ligand-activated androgen receptor. On the other hand, EGF decreases but androgen increases secretion of PSA.

Recently, PAP was suggested as being involved in the regulation of proliferative signal transduction in prostatic cancer cells (Meng et $a l ., 2000)$. The data suggest that expression of cellular PAP is important to maintain a slow growth rate and to preserve androgen sensitivity by dephoshorylating ErbB-2 on tyrosine residues. In the presence of androgen, AR is activated and leads to stimulation or suppression of transcription of target genes (Meng et al., 2000; Peterziel et al., 1999). The alteration of gene expression through an as yet unidentified mechanism results in a constitutively tyrosine-phosphorylated ErbB-2 protein. The cellular form of PAP is supposed to function as a negative regulator of the tyrosine phosphorylation signal by dephosphorylating phosphotyrosine on the c-ErbB-2 protein that leads to the down-regulation of prostate cell growth (Lin et al., 1998; Meng \& Lin, 1998). However, relatively little is known regarding the molecular mechanism of tissue-specific regulation of the expression of the PAP gene in prostate cells.

Here, we present results of the studies on early expression of the two most characteristic prostate proteins, PAP and PSA, at the level of their mRNAs in response to major steroid hormones (DHT, E) and growth factors (EGF, bFGF).

\section{MATERIALS AND METHODS}

Tissue samples. Samples of prostate tissues ( $\mathrm{n}=42$ ) from patients with diagnosed and histopathologically confirmed hyperplasia (age $72 \pm 10$ ) were collected at the time of surgery. The preparation of tissue slices was done as previously described (Dulińska et al., 1997).

Isolation of cells. To release epithelial secretory cells characteristic of the synthesis of PAP and PSA, a part of prostate tissue from the Surgery Unit was cut with a razor blade into small slices $(1 \mathrm{~mm} \times 1 \mathrm{~mm} \times 2 \mathrm{~mm})$ and continuously washed during the procedure with RPMI 1640 medium (Sigma) to remove blood and cell debris from the cut surfaces. Cells were released by overnight treatment of tissue slices with $0.125 \%$ trypsin, $0.05 \%$ EDTA in phosphate-buffered saline $\left(\mathrm{NaCl} / \mathrm{P}_{\mathrm{i}}\right), \mathrm{pH}$ 7.4, at $4^{\circ} \mathrm{C}$ (Van Helden et al., 1994). Afterwards slices were washed with the buffer and left for up to 4-6 weeks in RPMI 1640 with 5\% FCS. During this period the cells released attached to surface and their number was satisfactory. The slices were removed. The attached cells were cultured up to $72 \mathrm{~h}$.

Enzymatic and histochemical determination of PAP in isolated cells. Culture medium and cells were analyzed for PAP activity. The medium was collected and assayed directly with $20 \mathrm{mM}$ p-nitrophenyl phosphate (p-NPP) in $50 \mathrm{mM}$ Tris/HCl, pH 7.5. The cell layer was washed gently with $\mathrm{NaCl} / \mathrm{P}_{\mathrm{i}}$ and covered with $200 \mu \mathrm{l}$ of $200 \mathrm{mM}$ p-NPP solution in $50 \mathrm{mM}$ Tris $/ \mathrm{HCl}, \mathrm{pH}$ 7.5. In both cases absorbance at $400 \mathrm{~nm}$ was measured to assay PAP (Ostrowski \& Tsugita, 1961).

Alternatively, the presence of PAP in the cells isolated from the tissue was confirmed histochemically. Cells were fixed on a dish using $50 \%$ acetone in $10 \mathrm{mM}$ acetate buffer, $\mathrm{pH}$, 4.5, for $10 \mathrm{~min}$. Afterwards cells were incubated with napthyl phosphate $(2 \mathrm{mg} / 10 \mathrm{ml})$ and hexsazonium pararosanilin $(0.8 \mathrm{ml} / 10$ $\mathrm{ml}$ ) in the acetate buffer at $\mathrm{pH}$ 4.5. PAP activity was visualized as deep-red staining of the cells (Barka \& Andersson, 1962). 
The effect of steroid hormones and growth factors on the level of PAP and PSA mRNAs. Weighted (0.1-0.2 g) tissue slices or cells $\left(10^{5}-10^{6}\right)$ were incubated at $37^{\circ} \mathrm{C}$ in an incubator $\left(5 \% \mathrm{CO}_{2}\right.$ and $95 \%$ air, Green Line, ASSAB) for 1, 3, 4, 5 h or overnight in the RPMI 1640 medium containing 1\% L-glutamine, penicillin (100 units $/ \mathrm{ml}$ ), streptomycin $(100 \mu \mathrm{g} / \mathrm{ml})$ and $10 \%$ steroid free fetal calf serum (SF - charcoal-stripped fetal calf serum (Garcia-Arenas et al., 1995) without or with: DHT $\left(10^{-9}-10^{-11} \mathrm{M}\right), \mathrm{E}$ $\left(10^{-7}-10^{-9} \mathrm{M}\right)$, both DHT $\left(10^{-11} \mathrm{M}\right)$ and $\mathrm{E}$ $\left(10^{-7} \mathrm{M}\right), \mathrm{bFGF}(10 \mathrm{ng} / \mathrm{ml})$, EGF (10 $\left.\mathrm{ng} / \mathrm{ml}\right)$, both bFGF (10 $\mathrm{ng} / \mathrm{ml})$ and DHT $\left(10^{-11} \mathrm{M}\right)$, both EGF $(10 \mathrm{ng} / \mathrm{ml})$ and DHT $\left(10^{-11} \mathrm{M}\right)$.

Isolation of RNA and Northern blot analysis. Isolation of total RNA from human prostate tissue slices and Northern blot analysis were essentially done as previously described (Dulińska et al., 1997). Usually $0.2 \mathrm{mg}$ of RNA was obtained from $1 \mathrm{~g}$ of prostate tissue. In the case of RNA preparation from cultured cells (1.5-2.0 $\times 10^{7}$ cells/sample) they were harvested by rubber policeman, pelleted by centrifugation $(1000 \times \boldsymbol{g}$ for $6 \mathrm{~min})$, washed twice with $1 \times \mathrm{NaCl} / \mathrm{P}_{\mathrm{i}}$, lysed in guanidinium isothiocyanate solution and homogenized. Total RNA was then purified by centrifugation through a cesium chloride cushion. Alternatively, total RNA was also isolated from the cultured cells using the TRIzol reagent (Gibco).

The quality of RNA samples was always verified by spectrophotometric $\left(\mathrm{A}_{260} / \mathrm{A}_{280}\right)$ and electrophoretic (1.2\% agarose gel) analysis.

Statistical analysis. Statistical comparisons among population were performed using the SAS program for statistical analysis and verified based on Student's $t$-test (Daniels, 1999). Differences were considered significant when $P<0.05$.

\section{RESULTS}

Four deoxyribonucleotide probes corresponding to selected fragments of cDNAs of
PAP and PSA were used to study the effect of steroid hormones and growth factors on mRNA levels of these two prostate specific proteins in benign hyperplastic prostate tissue. Two of them: the 29-mer $5^{\prime}$-TGG GAC TTC GGT CTC CAT GCC GAA ACA CC-3' and 31-mer 5'-GGG ATC ACA GGG CCA ACC AGC TCA GCA AAC C-3', were identical to the fragments of the sense strand of PAP cDNA between positions 143-171 and 1087-1117, respectively (Vihko et al., 1988) and had been already successfully used (Dulińska et al., 1997). The next two, the 31 mer 5'-CTT GGT CAC CTT CTG AGG NGT GAA CTT GCG C-3' and 30 mer 5'-CAC CTG CCA GGG TTG GGA ATG CTT CTC GCA-3' were complementary to the fragments of the sense strand of PSA cDNA between positions 552-582, and 91-120, respectively (Watt et al., 1986). All the probes were labeled with ${ }^{32} \mathrm{P}$ and the preparations of the highest specific activities $(1 \mu \mathrm{Ci} / \mathrm{ng})$ were used to search the respective mRNAs in the prostate tissues studied and epithelial secretory cells derived from them. Such labeling allowed for 1-5 day exposure of the hybridized samples.

The analysis of total RNA samples isolated from a large number of benign hyperplastic prostate tissues $(\mathrm{n}=12)$ indicated the presence of mRNAs for PAP (about $3.3 \mathrm{~kb}$ ) and PSA (about $1.6 \mathrm{~kb}$ ). The sizes of mRNA for these prostate specific proteins remain in agreement with those reported previously (Dulińska et al., 1997). The intensity of both PAP and PSA mRNA bands depended on the composition of the medium in which slices of tissue were incubated (up to $24 \mathrm{~h}$ ) prior to RNA isolation. Clearly the addition of DHT, E, bFGF and EGF to the steroid free RPMI 1640 medium (SF) increased the intensities of bands representing both mRNAs (Fig 1). In each case they depended on the concentration of the steroid hormone and/or growth factor added as well as on time of incubation of BPH tissue slices in the medium (not shown).

DHT has been recognized as the most important factor that affects the metabolism of pros- 


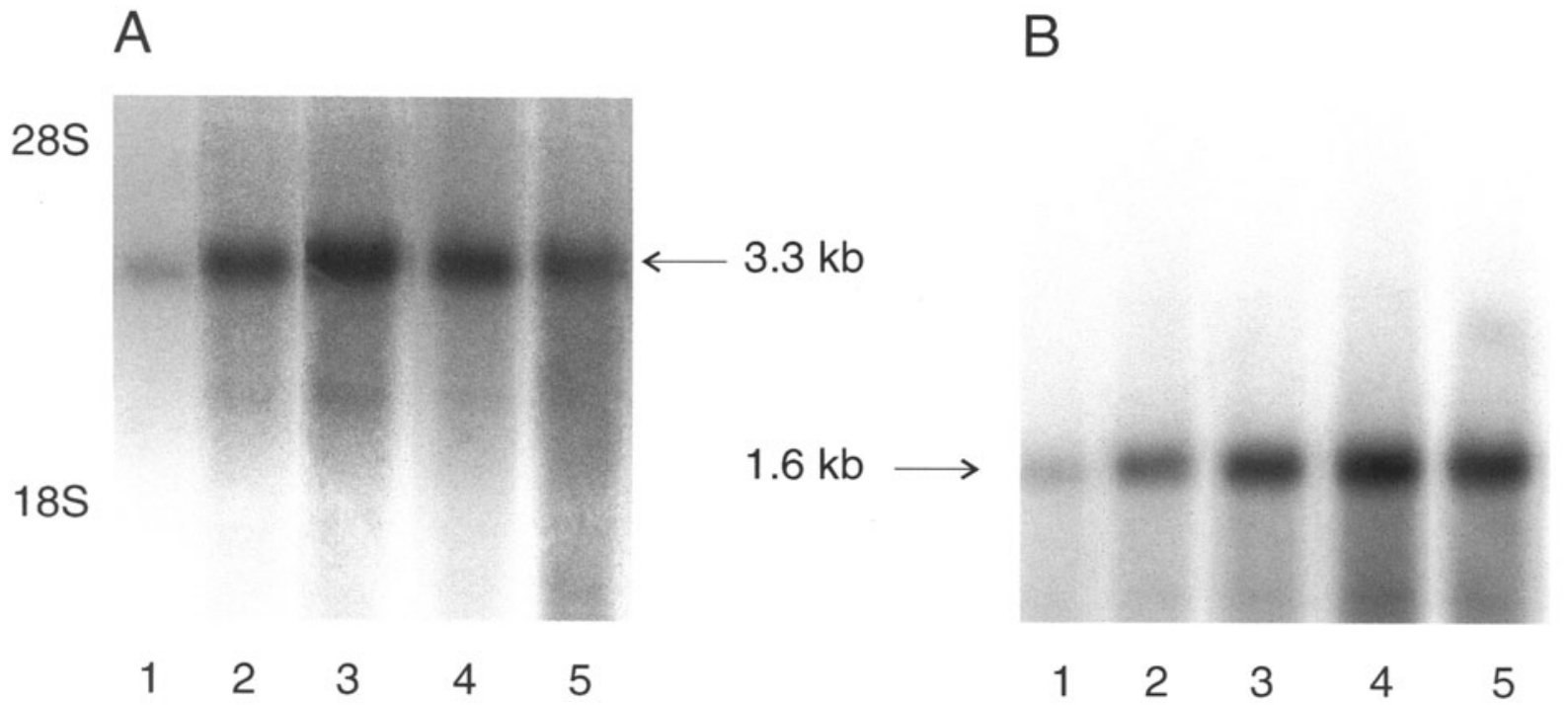

Figure 1. Northern blot analysis of PAP (A) and PSA (B) mRNAs in total RNA isolated from human prostatic tissue.

A. 1. $\mathrm{SF}, 2$. DHT $\left(10^{-11} \mathrm{M}\right), 3$. DHT $\left(10^{-11} \mathrm{M}\right)+\operatorname{bFGF}(10 \mathrm{ng} / \mathrm{ml}), 4$. DHT $\left(10^{-11} \mathrm{M}\right)+\mathrm{EGF}(10 \mathrm{ng} / \mathrm{ml}), 5$. DHT $\left(10^{-11}\right.$ $\mathrm{M})+\mathrm{E}\left(10^{-7} \mathrm{M}\right)$. B. 1. SF, 2. DHT $\left(10^{-11} \mathrm{M}\right)$, 3. DHT $\left(10^{-11} \mathrm{M}\right)+\mathrm{bFGF}(10 \mathrm{ng} / \mathrm{ml}), 4$. DHT $\left(10^{-11} \mathrm{M}\right)+\mathrm{EGF}(10$ $\mathrm{ng} / \mathrm{ml}), 5$. DHT $\left(10^{-11} \mathrm{M}\right)+\mathrm{E}\left(10^{-7} \mathrm{M}\right)$. Total RNA $(25 \mu \mathrm{g})$ from benign hyperplastic tissue was fractionated by electrophoresis (1.2\%) and afterwards hybridized to ${ }^{32}$ P-labeled specific oligonucleotide probes for PAP (A) or PSA (B) mRNA.

tate tissue (Dulińska et al., 1997; Kim et al., 1996). Our analysis of over 40 tissue samples from different $\mathrm{BPH}$ donors indicated unanimous reproducibility and statistical significance $(P<0.001)$ of the observed effect (Table 1).
We were able to show that PAP mRNA level increased significantly during the first few hours of incubation and reached the highest value -3 -fold increase of the initial level - after 3-5 h. The most profound effect - not less than 6-fold increase of PAP mRNA level in

Table 1. The effect of different concentrations of DHT $\left(10^{-7} \mathrm{M} / 10^{-11} \mathrm{M}\right)$ on the level of PAP mRNA in benign hyperplastic prostate tissue $(n=42)$.

Tissue slices were incubated for $1,2,3,4,5$ and $24 \mathrm{~h}\left(37^{\circ} \mathrm{C}, 5 \% \mathrm{CO}_{2}\right)$ with appropriate factors added to RPMI 1640 serum free medium (SF). The analysis of PAP mRNA was done as described under Materials and Methods.

\begin{tabular}{lllllllllllll}
\hline \multicolumn{1}{c}{ Level of PAP mRNA (percentage of initial value) } \\
\hline Time & $0 \mathrm{~h}$ & $1 \mathrm{~h}$ & & $3 \mathrm{~h}$ & & $4 \mathrm{~h}$ & & $5 \mathrm{~h}$ & & $24 \mathrm{~h}$ & \\
\hline DHT concn. (M) & mean & mean & S.D. & mean & S.D. & mean & S.D. & mean & S.D. & mean & S.D. \\
\hline SF (no DHT) & 100.0 & 86.50 & 14.50 & 68.81 & 10.81 & 48.60 & 14.77 & 44.52 & 12.92 & 18.33 & 9.35 \\
$10^{-11}$ & 100.0 & 175.80 & 14.80 & 252.00 & 25.20 & 330.0 & 33.0 & 302.50 & 38.00 & 259.50 & 40.00 \\
$10^{-10}$ & 100.0 & 165.00 & 18.10 & 201.20 & 20.20 & 298.00 & 36.15 & 289.50 & 31.20 & 259.85 & 33.00 \\
$10^{-9}$ & 100.0 & 165.00 & 24.10 & 179.00 & 27.00 & 211.50 & 23.00 & 202.65 & 29.20 & 169.00 & 22.25 \\
$2 \times 10^{-8}$ & 100.0 & 153.20 & 23.15 & 172.00 & 17.00 & 198.80 & 17.00 & 203.50 & 27.00 & 174.00 & 19.20 \\
$10^{-7}$ & 100.0 & 122.00 & 17.20 & 101.00 & 11.00 & 79.00 & 12.00 & 67.00 & 11.00 & 55.00 & 16.00 \\
\hline
\end{tabular}


comparison with its level in the sample of the same tissue incubated in parallel without DHT - was observed at 4th hour of incubation for $10^{-11} \mathrm{M}$ final concentration of DHT (Fig. 2).
bFGF/DHT (Fig. 3). Analogous experiments were carried out on cultured cells released from BPH tissue slices. The cells showed PAP activity as was confirmed by enzyme chemical

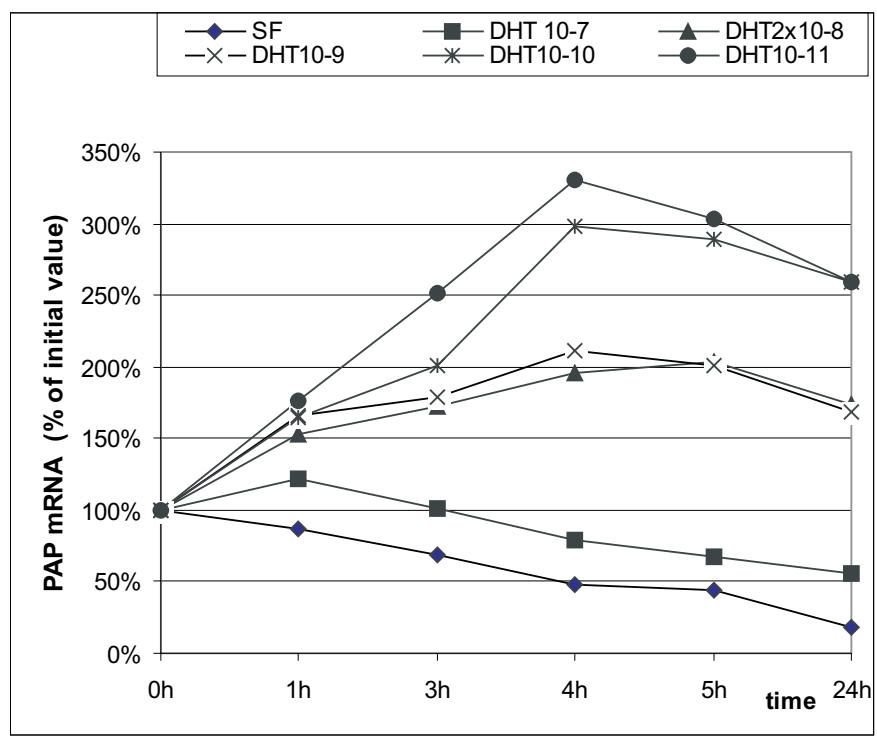

Figure 2. The effect of different concentrations of DHT $\left(10^{-7}-10^{-11} \mathrm{M}\right)$ on the level of PAP mRNA in benign hyperplastic prostate tissue $(n=42)$.

Presented are the mean values of mRNA levels (included in Table I) detected at various times of incubation.

Based on the results of studies on DHT effect on PAP mRNA level in BPH tissue slices the choice of $4 \mathrm{~h}$ incubation time was made to study short time effects of the remaining factors, such as E, EGF and bFGF. The addition of E, EGF or bFGF to the incubation medium caused approximately 2-fold increase of PAP mRNA level (Fig. 3). Supplementation of a DHT containing incubation medium with any of those factors led in each case to a statistically significant increase $(P<0.005)$ of PAP mRNA. The highest increase was observed for and histochemical assays (not shown). The same effects of steroid hormones and growth factors as those for tissue slices were observed (Fig. 4).

Parallel analysis of $\mathrm{BPH}$ tissue slices and cells derived from them for PSA mRNA showed quite similar effects when DHT, E, bFGF and EGF were used in the medium as the only factor or when DHT and one of the remaining factors were both present (Fig. 5 and Fig. 6). Again, DHT caused a 3-fold increase of the PSA mRNA. However, this time the high-

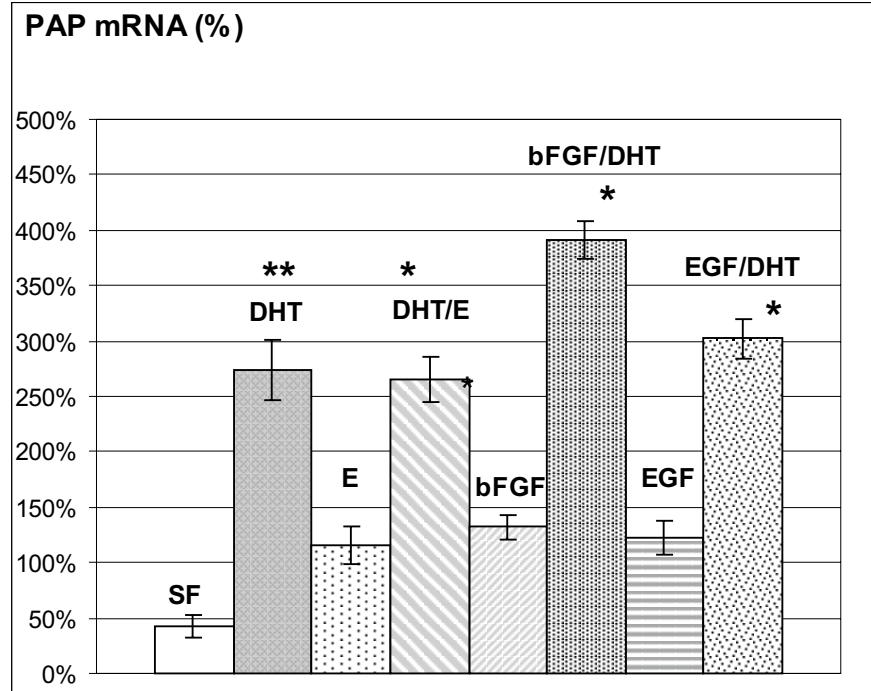

Figure 3. The effect of steroid hormones (DHT $10^{-11} \mathrm{M}, \mathrm{E} 10^{-7} \mathrm{M}$ ) or growth factors (bFGF $10 \mathrm{ng} / \mathrm{ml}$, EGF 10 $\mathrm{ng} / \mathrm{ml}$ ) on the level of PAP mRNA in benign hyperplastic prostate tissue $(n=$ 12).

Tissue slices were in each case incubated with appropriate factor(s) for $4 \mathrm{~h}\left(37^{\circ} \mathrm{C}, 5 \%\right.$ $\mathrm{CO}_{2}$ ) added to RPMI 1640 serum free medium (SF). The analysis of PAP mRNA was done as described under Materials and Methods. The PAP mRNA level was expressed as percentage of its initial level. *Significantly higher than control $(P<$ 0.05). ${ }^{* *}$ Significantly higher than control $(P$ $<0.005)$. 


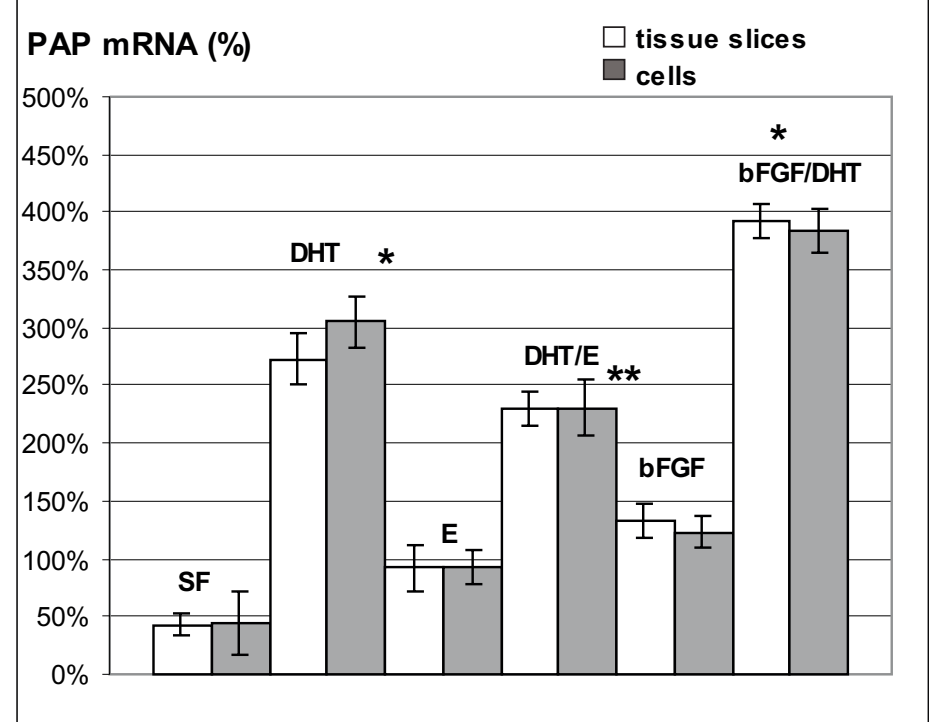

Figure 4. Comparison of the effect of $E$ $\left(10^{-7} \mathrm{M}\right)$, E/DHT $\left(10^{-7} \mathrm{M} / 10^{-11} \mathrm{M}\right)$, DHT $\left(10^{-11} \mathrm{M}\right)$ and $/$ or bFGF $(10 \mathrm{ng} / \mathrm{ml})$ on the level of PAP mRNA in BPH tissue slices and cultured cells derived from them $(n=12)$.

The PAP mRNA level was expressed as percentage of its initial level. *Significantly higher than control $(P<0 \quad .05) .{ }^{* *}$ Significantly higher than control $(P<0.001)$.

est (10-fold) and most significant $(P<0.001)$ increase of PSA mRNA level was observed for tissue samples incubated in medium containing both DHT and EGF (Fig. 5) rather than DHT and bFGF as it was in the case of PAP mRNA level (Fig. 3).

The addition of $\mathrm{E}$ to incubation medium either in the case of tissue slices or cultured cells derived from the same BPH tissue led to a 2-fold increase of PAP as well as PSA mRNA levels in comparison with the 5-6 fold increase if DHT was used as the only factor (Figs. 4 and 6). Supplementation of a DHT containing medium with $\mathrm{E}$ did not bring about any change in PAP mRNA level (Fig. 4) and significant increase $(P<0.001)$ in the case of
PSA mRNA level (Fig. 6). Thus E by itself did not seem to affect either PAP or PSA mRNA levels as much as DHT did in short term incubation of tissue slices or cells derived from them. Perhaps it nonspecifically sustains transcription from both the PAP and PSA genes and/or increases stability of the respective mRNAs. E has a different effect on PAP and PSA mRNA levels if DHT is also present in the medium (Figs. 4 and 6).

\section{DISCUSSION}

There is no single experimental model that could be used for studies of BPH in humans.

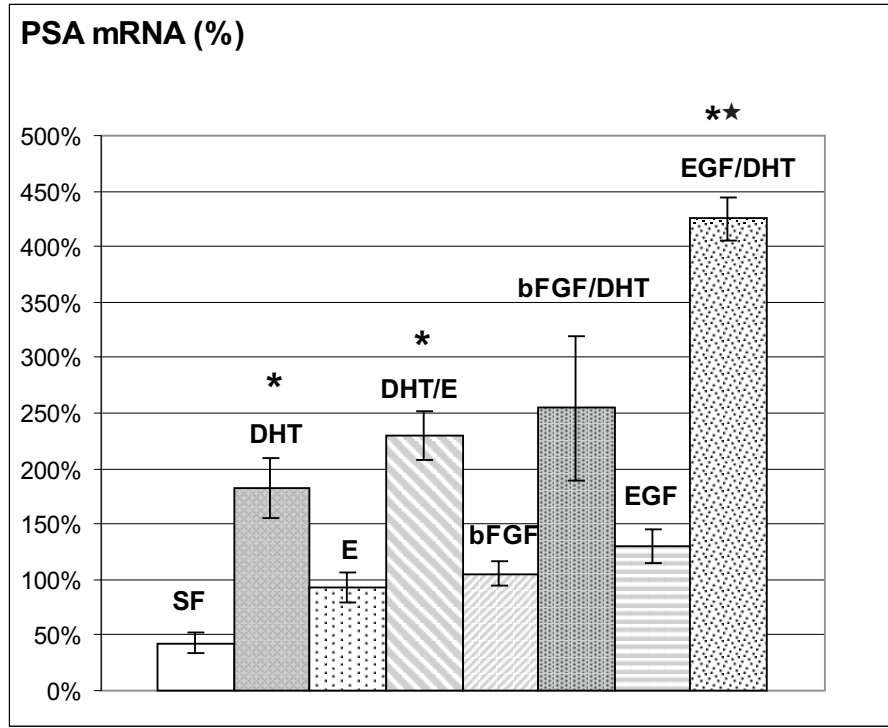

Figure 5. The effect of steroid hormones (DHT $10^{-11} \mathrm{M}, \mathrm{E} 10^{-7} \mathrm{M}$ ) or growth factors (bFGF $10 \mathrm{ng} / \mathrm{ml}$, EGF $10 \mathrm{ng} / \mathrm{ml}$ ) on the level of PSA mRNA in benign hyperplastic prostate tissue ( $n$ = 12).

Tissue slices were incubated for $4 \mathrm{~h}\left(37^{\circ} \mathrm{C}\right.$, $5 \% \mathrm{CO}_{2}$ ) with appropriate factor(s) added to RPMI 1640 serum free medium (SF). The analysis of PSA mRNA was done as described under Materials and Methods. The PSA mRNA level was expressed as percentage of its initial level. *Significantly higher than control value $(P<0.05)$. ${ }^{* *}$ Significantly higher than control value $(P<$ 0.001). 


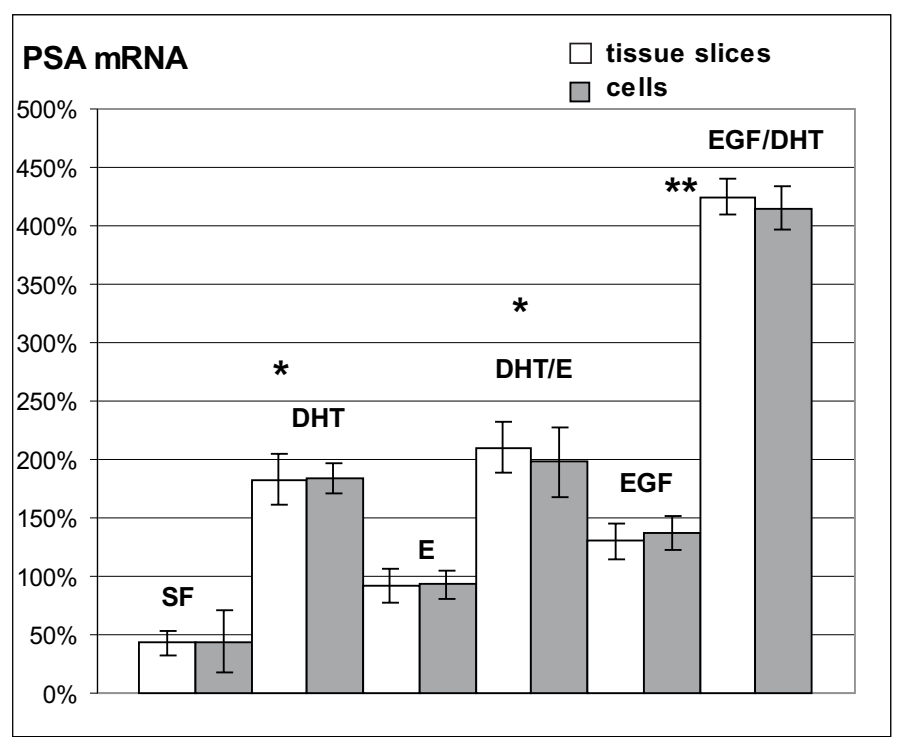

Figure 6. Comparison of the effect of $\mathrm{E}$ $\left(10^{-7} \mathrm{M}\right)$, E/DHT $\left(10^{-7} \mathrm{M} / 10^{-11} \mathrm{M}\right)$, DHT $\left(10^{-11} \mathrm{M}\right)$ and/or EGF $10 \mathrm{ng} / \mathrm{ml}$ on the level of PSA mRNA in BPH tissue slices and derived from them cultured cells (n = 12).

The PSA mRNA level was expressed as percentage of its initial level. *Significantly higher than control value $(P<0.05)$. **Significantly higher than control value $(P<$ 0.001).

We recently successfully studied the effect of DHT on mRNA level of PAP in BPH using tissue slices kept in culture conditions for up to 72 h (Dulińska et al., 1997). DHT, EGF and bFGF affect the proliferation of prostate epithelial as well as stromal cells (Kim et al., 1996; Tenniswood et al., 1990). To avoid the interference of the proliferative effect shortterm cultures seem to offer an advantage and allow one to observe the influence of a steroid hormone or GF on the expression of genes of interest minimizing the effect of cell growth and proliferation.

Using that model we recently reported that DHT is an important factor sustaining the expression of PAP mRNA in BPH (Dulińska et $a l .$, 1997). The present study clearly indicated DHT as a major factor that affects the expression of not only PAP but also the PSA gene and/or the stability of the respective mRNAs in benign hyperplastic prostate tissue. In a short time scale experiments the differences between the mRNA levels for both these prostate-specific proteins - isolated from tissue slices or cells derived from them - incubated in a medium supplemented with DHT and without the hormone, were significant.

Bearing in mind that the prostate is an androgen-responsive organ (Isaacs, 1994) it is not surprising that DHT, a major androgen of prostate epithelial and stromal cells so seriously affects the level of the mRNAs of PAP and PSA, the most characteristic proteins of this gland. The results obtained from measurements of PAP and PSA serum levels in cancer patients after endocrine therapy suggested a similar androgen dependency for the regulation of expression of both these genes (Pamies \& Crawford, 1996). In contrast, in $\mathrm{LNCaP}$ cell line the expression of PAP at the mRNA level was decreased, while that of PSA remained essentially the same upon DHT treatment (Henttu et al., 1992). The diminished expression of PAP in high passages of LNCaP cells might indicate that adrogenic transcriptional modulation of PAP expression changes upon passages. It is also possible that the decreased expression of PAP could have been due to de-differentiation of LNCaP cells following in vitro passages, since PAP is the major prostate-epithelium differentiation antigen (Lin et al., 1998). In ALVA-31 prostate carcinoma cells the decrease in the expression of PAP leading to its final loss was consistent throughout continued passages of the cells indicating the possible biological significance of low PAP expression as a marker of a high grade/stage tumors (Garcia-Arenas et al., 1995). If it is the case, our observation of the stimulatory effect of DHT on PAP mRNA level reflects the differences between the biological status of BPH tissue and cancer cells. The increase of PSA mRNA level in response to DHT stimulation suggests that in BPH tissue both 
genes are similarly controlled via androgens and that both genes contain androgen responsive elements. This corresponds well with the results obtained by Nevalainen et al. (1993) who have shown that androgens increased the level of PSA mRNA by activating transcription of the PSA gene containing an androgen responsive element in the promoter region.

Although the mechanisms leading to the development of human BPH are still largely unknown, there are several findings that suggest an involvement of $\mathrm{bFGF}$ in the pathogenesis. bFGF is expressed in hyperplastic prostates, where its concentration is as much as 2 or 3 times higher than in the normal prostate (Mydlo et al., 1988). bFGF is also well known as a growth-stimulating factor for prostatic stromal and epithelial cells in vitro (Geller, 1990; Sherwood et al., 1992). Finasteride - a potent and specific inhibitor of type II 5 - $\alpha$-reductase - reduces circulating and intraprostatic DHT levels (McConnell et al., 1992). The reduction of bFGF expression caused by finasteride in $\mathrm{BPH}$ specimens confirms the importance of the role of bFGF in the development of this condition. Reduced level of DHT could negatively affect bFGF transcription. Several studies support the view on a direct effect of androgens on bFGF gene regulation at the transcription level. Saez et al. (1999) conclude that finasteride could act as a negative regulator of bFGF expression and thus counteract the role of $\mathrm{bFGF}$ in the development of BPH. Our results showing an undoubtedly synergistic effect of bFGF and DHT especially on the expression and/or stability of PAP mRNA reflect the different and independent modes of action of this growth factor on prostatic cell proliferation and on the expression on the PAP gene or its mRNA stability.

Many studies focused on the co-regulation of the androgens and growth factors in prostatic cancer growth. Frydenberg et al. (1991) reported that EGF might also mediate the prostatic growth influenced by the androgenic milieu. The nature of the interactions between androgens and EGF in prostate cancer remains unclear although according to some authors androgens do not regulate the EGF-receptor expression, while, for most of them they do (Frydenberg et al., 1991; Shuurmans et al., 1991). Janssen et al. (1995) reported that DHT and EGF have a synergistic or an antagonistic effect on each other in respect to the cell kinetics of three prostate cancer cell lines - two androgen-insensitive PC-3 and DU-145 and the androgen-sensitive LNCaP model.

A recently formulated hypothesis pointed to DHT as an important factor that through decreased expression and/or inactivation of PAP causes uncontrolled stimulation of the EGF signal pathway and, in consequence, prostate cell proliferation (Lin et al., 1998; Zelivianski et al., 2000). This supports the view that sex steroids act on cell proliferation mainly indirectly, modulating the production and/or activity of growth factors. Our studies indicated a strongly synergistic effect of EGF and DHT on the expression and/or stability of PSA mRNA. This contradictory observation in light of the results of Meng et al. (2000) suggests different mechanisms of regulation of expression of important prostate tissue genes in $\mathrm{BPH}$ and in prostatic cancer cells. It also strengthens the view that PSA and PAP genes in $\mathrm{BPH}$ are expressed via various though partially analogous (effect of DHT) mechanisms.

The hypothesis of a primary stromal abnormality in BPH is supported by the findings of an increased activity of 5 - $\alpha$-reductase and of the high content of estrogens and their receptors in the stroma. In human $\mathrm{BPH}$ tissue estradiol, acting in association with sex hormone binding globulin (SHBG) produces an 8-fold increase in the cellular cAMP levels, primarily in the stroma (Rosner et al., 1999). The effect is mediated by DHT, which restrains the binding of estradiol to SHBG. It is also possible that estrogens may increase the responsiveness of human BPH stromal cells to androgens by up-regulating AR levels. The 
binding of estradiol or progesterone to ARs not only increased the proliferation of LNCaP, but also elicited effects on the mRNAs originating from androgen-regulated genes that were compared to those elicited by the androgenic steroids. The level of PAP and hAR mRNAs decreased in LNCaP cells treated with estradiol or progesterone and the synthetic androgen R1881 as well as in cells treated with R1881 alone. On the other hand, estradiol increased the level of PSA mRNA. Thus our results on the effect of estradiol on PAP and PSA mRNA expression and stability, similarly as in the case of bFGF and EGF, showed different modulation by E of PAP and PSA gene expression and/or their mRNA stability in BPH and in prostate cancer cells.

Further studies are required to assess what regulatory mechanisms that include both DHT and bFGF as well as EGF are involved in the control of the expression of the PAP and PSA genes in $\mathrm{BPH}$.

The authors wish to thank Professor Jerzy Stachura (Department of Pathomorphology, Collegium Medicum, Jagiellonian University, Kraków) for histopathological verification of the tissues studied and Professor Jan Litwin (Department of Histology, Collegium Medicum, Jagiellonian University, Kraków) for valuable discussion concerning cell culture.

\section{R E F E R E N C E S}

Barka T, Andersson PJ. (1962) Histochemical methods for acid phosphatase using pararosanilin as coupler. J Histochem Cytochem.; 10: 741-53.

Cooper AC, Foti A. (1974) A radioimmunoassay for prostatic acid phosphatase. Investig Urol.; 12: $98-102$.

Daniels WW. (1999) Biostatistics: a fundation for analysis in the health science, New York, Wiley $\mathrm{J}$ and Sons.
Diamandis EP, Yu H. (1995) New biological functions of prostate-specific antigen? J Clin Endocrinol Metab.; 80: 1515-7.

Dulińska J, Laidler P, Ostrowski WS, Mrozicki S, Gałka M. (1997) The effect of dihydrotestosterone on transcription of prostatic acid phosphatase mRNA in human hyperplastic gland. Acta Biochim Polon.; 44: $751-8$

Farnsworth WE. (1996) Roles of estrogen and SHBG in prostate physiology. Prostate.; 28: $17-23$

Frydenberg M, Foo TM, Jones AS, Grace J, Hensley WJ, Rogers J, Pearson BS, Raghavan D. (1991) Benign prostatic hyperplasia - video image analysis and its relationship to androgen and epidermal growth factor receptor expression. $J$ Urol.; 146: 872-6.

Garcia-Arenas R, Lin FF, Lin D, Jin LP, Shih CC-Y, Chang C, Lin MF. (1995) The expression of prostate acid phosphatase is transcriptionally regulated in human prostate carcinoma cells. Mol Cell Biol.; 111: 29-37.

Geller J. (1990) Effect of finasteride, a $5 \alpha$-reductase inhibitor on prostate tissue androgens and prostate-specific antigen. $J$ Clin Endocrinol Metab.; 71: 1552-5.

Guenette RS, Tenniswood M. (1994) The role of growth factors in the suppression of active cell death in the prostate: an hypothesis. Biochem Cell Biol.; 72: 553-9.

Henttu P, Vihko P. (1992) Steroids inversely affect the biosynthesis and secretion of human prostatic acid phosphatase and prostatespecific antigen in the LNCaP cell line. J Steroid Biochem Mol Biol.; 41: 349-60.

Henttu P, Liao S, Vihko P. (1992) Androgens up-regulate the human prostate-specific antigen messenger ribonucleic acid (mRNA), but down-regulate the prostatic acid phosphatase mRNA in the LNCaP cell line. Endocrinology; 130: $766-72$.

Heston WD. (1996) Significance of prostate-specific membrane antigen (PSMA) a neurocarboxypeptidase and membrane folate hydrolase. Urology A.; 35: 400-7. 
Isaacs JT. (1994) Role of androgens in prostatic cancer. Vitamins Horm.; 49: 433-502.

Janssen T, Kiss R, Dedecker R, Petein M, Pasteels JL, Schulman C. (1995) Influence of dihydrotestosterone, epidermal growth factor, and basic fibroblast growth factor on the cell kinetics of the PC3, DU 145, and LNCaP prostatic cancer cell lines: relationships with DNA ploidy level. Prostate.; 27: 277-86.

Kim IY, Kim JH, Zelner DJ, Ahn HJ, Sensibar JA, Lee Ch. (1996) Transforming growth factor- $\beta 1$ is a mediator of anrdogen-regulated growth arrest in an androgen-responsive prostatic cancer cell line, LNCaP. Endocrinology.; 137: 991-9.

Krieg M, Bartsch W, Herzer S, Becker H, Voigt KD. (1977) Quantification of androgen binding, androgen tissue levels, and sex hormone-binding globulin in prostate, muscle and plasma of patients with benign prostatic hypertrophy Acta Endocrinol (Copenh).; 86: 200-15.

Lin MF, Garcia-Arenas R, Chao Ych, Lai MMC, Patel PC, Xia XZ. (1993) Regulation of prostatic acid phosphatase expression and secretion by androgen in LNCaP prostate carcinoma. Arch Biochem Biophys.; 300: 384-90.

Lin MF, Meng TC, Rao PS, Chang C, Schonthal AH, Lin FF. (1998) Expression of human prostatic acid phosphatase correlates with androgen-stimulated cell proliferation in prostate cancer cell lines. J Biol Chem.; 273: 5939-47.

McConnell JD, Wilson JD, George FW, Geller J, Papppas F, Stoner E. (1992) Finasteride, an inhibitor of $5 \alpha$-reductase, suppresses prostatic dihydrotestosterone in men with benign prostatic hyperplasia. J Clin Endocrinol Metab.; 74: 505-8.

Meng TC, Lin MF. (1998) Tyrosine phosphorylation of c-ErbB-2 is regulated by the cellular form of prostatic acid phosphatase in human prostate cancer cells $J$ Biol Chem.; 273: 22096-104.

Meng TC, Lee MS, Lin MF. (2000) Interaction between protein tyrosine phosphatase and protein tyrosine kinase is involved in andro- gen-promoted growth oh human prostate cancer cells. Oncogene.; 19: 2664-77.

Murtha P, Tindall DC, Young CY. (1993) Androgen induction of a human prostate-specific kallikrein, hKLK2: characterization of an androgen response element in the $5^{\prime}$ promoter region of the gene. Biochemistry.; $\mathbf{3 2}$ : 6459-6464.

Mydlo J, Michaeli, J, Heston, W, Fair W. (1988) Expression of basic fibroblastic growth factor mRNA in benign prostatic hyperplasia and prostatic carcinoma. Prostate; 13: 241-7.

Nevalainen MT, Harkonen PL, Valve EM, Ping W, Nurmi W, Martikainen PM. (1993) Hormone regulation of human prostate in organ culture. Cancer Res.; 53: 5199-207.

Ostrowski W, Tsugita A. (1961) Purification of acid phosphomonoesterase from human prostate gland. Arch Biochem.; 94: 68-73.

Pamies RJ, Crawford DR. (1996) Tumor markers. An update. Med Clin North Am.; 80: 185-99.

Peterziel H, Mink S, Schonert A, Becker M, Klocker H, Cato ACB. (1999) Rapid signaling by androgen receptor in prostate cancer cells. Oncogene.; 18: 6322-9.

Pilarsky CP, Schmidt U, Eissrich C, Stade J, Froschermaier SE, Haase M, Faller G, Kirchner TW, Wirth MP. (1998) Expression of the extracellular matrix signalling molecule Cyr61 is downregulated in prostate cancer. Prostate.; 36: 85-91.

Robert M, Gibbs B.F, Jacobsen T, Gangon C. (1995) Characterization of prostate specific antigen proteolitic activity on its major physiological substrate, the sperm motility inhibitor precursor/semenogelin I. Biochemistry.; 36: $811-6$.

Rosner W, Hryb DJ, Khan MS, Nakhla AM, Romas NA. (1999) Sex hormone-binding globulin mediates steroid hormone signal transduction at the plasma membrane. J Steroid Biochem Molec Biol.; 69: 481-5.

Saez C, Gonzalez-Baena AC, Japon MA, Giraldez J, Segura DI, Rodriguez-Vallejo JM, Gonzalez-Esteban J, Miranda G, Torrubia F. (1999) Expression of basic fibroblast growth factor 
and its receptors FGFR1 and FGFR2 in human benign prostatic hyperplasia treated with finasteride. Prostate.; 40: 83-8.

Sherwood ER, Fong CJ, Lee C, Kozłowski JM. (1992) Basic fibroblast growth factor: a potential mediator of stromal growth in the human prostate. Endocrinology.; 130: 2955-63.

Shuurmans ALG, Bolt J, Veldscholte J, Mulder E. (1991) Regulation of growth factors and steroid hormones. J Steroid Biochem Mol Biol.; 40: 193-7.

Solin T, Kontturi M, Pohlmann R, Vihko P. (1990) Gene expression and prostate specificity of human prostatic acid phosphatase (PAP): evolution by RNA blot analyses Biochim Biophys Acta.; 1048: 72-7.

Tenniswood MP, Montpetit NL, Leger JG, Wong P, Pineault JM, Rouleau M. (1990) Epithelial-stromal interactions and cell death in the prostate. In The prostate as an endocrine gland. Fornsworh WE, Ablin RJ. eds, pp 187-207. CRC Press, Boca Raton, Fla.
Van Helden PD, Wiid IJF, Hoal-van Helden EG, Bey E, Cohen, R. (1994) Detection by DNA fingerprinting of somatic changes during the establishment of a new prostate cell line $\mathrm{Br} J$ Cancer.; 70: 195-8.

Vihko P, Virkkunen P, Henttu P, Roiko K, Solin T, Huhtala ML. (1988) Molecular cloning and sequence analysis of cDNA encoding human prostatic acid phosphatase. FEBS Lett.; 236: 275-81.

Watt KWT, Lee PJ, M'Timkulu T, Chan WP, Loor R. (1986) Human prostate-specific antigen: structural and functional similarity with serine proteases. Proc Natl Acad Sci U S A.; 83: $3166-70$.

Zelivianski S, Larson C, Seberger J, Taylor R, Lin MF. (2000) Expression of human prostatic acid phosphatase gene is regulated by upstream negative and positive elements Biochim Biophys Acta.; 1491: 123-32. 